\title{
Tensões entre pesca, turismo e exploração de gás reconfigurando ruralidade na ilha de Boipeba - BA
}

\section{Tensions Between Fishing, Tourism and Gas Exploration Reconfiguring Rurality in Boipeba Island}

\author{
Cristina Maria Macêdo de ALENCAR*
}

\begin{abstract}
RESUMO
Compreendendo-se que o desenvolvimento é um processo histórico em constante movimento, gerador de avanços e retrocessos na superação das desigualdades sociais, contemporaneamente denominadas assimetrias, examina-se a dinâmica social cotidiana na ilha de Boipeba, município de Cairu-BA, e integrante da APA Tinharé - Boipeba, impactada pela questão ambiental e pelo desenvolvimento turístico da Costa do Dendê. Periodiza-se nesse processo o surgimento da atividade de exploração de gás, em janeiro de 2007, quando foram iniciadas as atividades de produção de gás no Campo de Manati BCAM-40, localizado na Bacia Camamu-Almada, o que vem acompanhado das regulações ambientais específicas. Questiona-se se o cumprimento da regulação ambiental tem interferido na vida da população da ilha, dando-se centralidade à pesca artesanal como atividade econômica estruturante do local em seu modo de vida rural, na relação com o turismo e com a produção de gás como indução exógena. A pesquisa foi realizada com bases documental e de campo (2009 e 2010) e aponta como resultados que as atividades turísticas e de exploração de gás constituem um fenômeno (des)organizativo do rural pesqueiro, o que parece ter sido acirrado com a ingerência dos agentes ambientais desde os estudos de impacto ambiental, passando pelo relatório de impacto ambiental e chegando com reforço de assimetrias à intervenção para compensação ambiental.
\end{abstract}

Palavras-chave: questão socioambiental; desenvolvimento; tensões e reprodução social.

\begin{abstract}
As we realize that development is a historical process in constant movement that generates advances and setbacks to overcome social inequalities - currently known as asymmetries - this article examines the social daily dynamics on the island of Boipeba, city of Cairu, Bahia, and member of APA Tinhare - Boipeba, which is impacted by environmental issues and developing tourism in Costa do Dendê. In that process the appearance of gas exploration in January 2007 is periodized, when the activities of gas production began in the Manati Field BCAM-40, located in the Camamu-Almada Basin, which comes
\end{abstract}

\footnotetext{
" Economista, doutora em Ciências Sociais do Desenvolvimento, Agricultura e Sociedade. Universidade Católica do Salvador, Programa de Pós-Graduação em Planejamento Territorial e Desenvolvimento Social e Mestrado Profissional em Planejamento Ambiental Email: cristinamm@ucsal.br
} 
with specific environmental regulations. It is questioned whether the compliance with environmental regulations has interfered in the life of the population of the island, giving importance to fishing as an economic activity that structures the site in its rural way of life in relation to tourism and gas production as exogenous induction. The research was based on documental and field data (2009 and 2010), and its results show that tourist activities and gas exploration constitute a (dis) organizational phenomenon of the rural fishing that seems to have been strained with the mismanagement of environmental agents since the studies of environmental impact, through the environmental impact report and coming up with the increase of asymmetry compensation for environmental intervention.

Key-words: socio-environmental issue; development; tensions and social reproduction.

\section{Introdução}

As relações entre sociedade e natureza têm sido examinadas contemporaneamente tanto com centralidade na sociedade (conflitos, cidadania, justiça etc.) quanto com centralidade na natureza biofísica (ambiente, poluição, degradação), pondo em diálogo as áreas das ciências naturais com as das ciências sociais e vice-versa. $\mathrm{O}$ contexto geral desse debate marca um amplo movimento de crítica ao conhecimento científico (relações ciência e sociedade, interdisciplinaridade, pensamento complexo, epistemes relacionais etc.) e ao padrão de desenvolvimento social do planeta (teoria crítico-social, movimentos sociais, revisões teóricas, modernidade, pós-modernidade, institucionalidades, ressurgimento e ressignificações de categorias como desenvolvimento, território, rural, identidades sociais etc.) dialeticamente sob condicionantes capitalistas da globalização.

Nosso foco ao examinar a relação entre sociedade e natureza é o mundo rural como construção socio-histórica do lugar de trabalho e vida (HERÉDIA, 1979; WANDERLEY, 2000), cuja conflitualidade produz contingências de reprodução social de onde emergem as identidades sociais cientificamente elaboradas como ruralidades (MOREIRA, 2002; CARNEIRO, 1998; CASTRO-GÓMEZ, 2001; DURÁN, 1999; WANDERLEY, 2000; CONCHEIRO, 2006; VEIGA, 2006). Desse modo, compreende-se que o desenvolvimento é um processo histórico desigual e combinado (BRANDÃO, 2007; PEDRÃO, 2009), em constante movimento gerador de avanços e retrocessos na superação das desigualdades sociais. Nesse processo, a apropriação privada da natureza tem se constituído em frente de acu- mulação de capital e a tentativa sócio-histórica de superar essas desigualdades pelas regulações institucionais tem, paradoxalmente, produzido assimetrias dissimuladas pela suposta simetria social da regulação. É este o cerne da dinâmica socioambiental aqui examinada, isto é, os conflitos estruturais da sociedade capitalista que emergem do direito à propriedade privada e daquilo que seja bem coletivo, como a terra e a biodiversidade, tornam-se mais complexos à medida que, se desdobrando em múltiplas tensões no processo de desenvolvimento, não são enfrentados enquanto padrão de sociedade a ser superado, mas "orientados para a administração da mudança” (TOURAINE, 1989, p. 18).

Em janeiro de 2007, foram iniciadas as atividades de produção de gás no Campo de Manati BCAM-40, localizado na Bacia Camamu-Almada, a cerca de $10 \mathrm{~km}$ da ilha de Tinharé. O Consórcio Manati, representado pelas empresas Queiroz Galvão, Norse Energy e Petrobrás, operadora do empreendimento, desenvolve um sistema de produção e escoamento de gás natural naquele campo (PETROBRÁS, 2007). Esta atividade é considerada de significativo impacto ambiental e atende a legislações e cuidados específicos, cuja área de influência direta inclui a ilha de Boipeba, distrito do município de Cairu-BA, e integrante da APA Tinharé - Boipeba.

Examina-se a dinâmica social cotidiana na ilha de Boipeba ${ }^{1}$ como impactada pela questão ambiental e pelo desenvolvimento turístico da Costa do Dendê. Como dinâmica socioambiental, caracteriza-se o cotidiano dos moradores da Ilha de Boipeba pela interação entre as atividades pesqueira, de turismo e de exploração de gás, sob regulação ambiental. Neste contexto, questiona-se se o cumprimento da regulação ambiental tem interferido na

\footnotetext{
'Além da vila de Velha Boipeba, na ilha de Boipeba há as vilas de São Sebastião (Cova da Onça), de Monte Alegre e Moreré, onde ficam as praias de Barra, Prainha, Ponta dos Castelhanos, São Sebastião, Moreré, Cueira, Tassimirim e Bainema.
} 
vida da população da ilha, dando-se centralidade à pesca artesanal como atividade econômica estruturante do local em seu modo de vida rural, na relação com o turismo e com a produção de gás enquanto induções exógenas.

Assim, a relação entre sociedade e natureza se afirma pela conflitualidade, donde emergem as tensões provocadas pelas dinâmicas econômicas, e sua apreensão é possibilitada epistemologicamente pelo pensamento complexo (MORIN, 1996; BOAVENTURA, 1995; D’AMBRÓSIO, 1999; LEFF, 2009) a partir da matriz teórica crítico-social (BENSAÏD, 1999; MOREIRA, 1999; LEFF, 2009). Com abordagem metodologicamente qualitativa, partimos do exame de diagnósticos e das propostas compensatórias elaboradas pelo consórcio institucional contratado pela Petrobrás. Do exame documental, chamou-nos a atenção a recorrência dos mesmos informantes locais nos produtos das consultorias voltadas à implementação de medidas compensatórias aos impactos socioambientais decorrentes da exploração de gás, como previsto na Constituição Federal, Art. $225, \S 1^{\circ}$, IV e $\S 2^{\circ}$. A Licença de Instalação $n^{\circ}$ $317 / 2005$, estabelecida pelo Instituto Brasileiro de Meio Ambiente e Recursos Naturais - IBAMA -, institui diretrizes para os planos de compensação e desenvolvimento de projetos socioambientais que deram origem ao Programa Integrado de Projetos Produtivos de Desenvolvimento Socioambiental com Comunidades da Área de Influência Direta do Projeto Manati - PIPP. Estão no Programa as medidas compensatórias ou mitigadoras previstas no EIA/ RIMA, documentos exigidos para atividades potencialmente poluidoras, conforme Resoluções CONAMA 001/86, art. $6^{\circ}$ e Res. $237 / 97$, art. $3^{\circ}$ e Anexo I, ambas amparadas pela Lei 6.938/81 da Política Nacional do Meio Ambiente.

As portas que já estavam abertas em termos de disponibilidades de informações para pesquisas, para o nosso grupo de pesquisa Desenvolvimento, Sociedade e Natureza (UCSAL), em decorrência da fase geológica, ambiental e biológica desta pesquisa, eram as mesmas que já apareciam nos documentos examinados; as mesmas portas se abriram também para a pesquisa sobre dimensões socioeconômicas, disponibilizando os mesmos informantes. Isto aguçou nossa curiosidade científica em termos de representatividade qualitativamente dialética das informações assim obtidas.

Já se tem consensuado no campo da ciência ambiental que as pessoas que habitam os lugares são elementos-chave a serem considerados no ambiente. Nesse sentido, para implantação da atividade de produção de gás em área do arquipélago Tinharé - Boipeba, foram realizados diagnós- ticos detalhados, como o Relatório Descritivo Participativo contratado pela El Paso Corporation junto à empresa SOMA - Desenvolvimento e Meio Ambiente -, onde se explicitam a importância da comunidade pesqueira e o uso da metodologia de diagnóstico rápido participativo para caracterização socioambiental.

O presente documento refere-se à Revisão 01 das atividades realizadas pelo Projeto de Compensação da Atividade Pesqueira no âmbito da Segunda Campanha de Perfuração da El Paso no Bloco BM-CAL-4, Bacia de Camamu/Almada, de acordo com a Licença de Perfuração 070/2007 de 11 de Janeiro de 2007. O referido projeto promove ainda a continuidade de ações e programas que a El Paso vem mantendo na região do Baixo-Sul desde 2002 voltados ao segmento da pesca artesanal.

A fase II do projeto de compensação está relacionada à execução do Diagnóstico Rápido e Participativo (DRP) nas nove comunidades pesqueiras situadas na Área de Influência Direta da referida campanha, de forma a descrever os resultados obtidos e subsidiar a próxima etapa do projeto, que seja: retorno às comunidades para devolver e analisar coletivamente os resultados do diagnóstico e eleger as prioridades para a definição e construção dos projetos socioambientais a serem implementados, um em cada comunidade pesqueira (EL PASO \& SOMA, 2007).

A interação entre homem e ambiente no local onde habita tem sido legitimamente reivindicada como justificativa para o uso dessa metodologia em diagnósticos socioambientais, como também a interação entre o conhecimento certificado e o não certificado. Gomes et al. (2001), citados por Silva (2007), afirmam que haveria, nessa perspectiva, a possibilidade de "recolocação do saber técnico-científico em um nível não superior, mas de colaboração com grupos sociais providos de saberes engendrados na sua prática produtiva e nas suas relações sociais" (GOMES et al., 2001). Esse entendimento converge para as reflexões de Oliva (1999) sobre as relações de comprometimento do conhecimento científico com a sociedade enquanto os consensos paradigmáticos estabelecidos nas comunidades científicas requerem diálogos com as comunidades não científicas.

Para além do diálogo entre saberes, enquanto sujeitos sociais - consultores, técnicos que atuam na prospecção de gás, empresários do turismo, turistas, pescadores artesanais, moradores de Boipeba-, constituem segmentos sociais em 
desigualdade de condições socioeconômicas e institucionais. Como localidade, a ilha de Boipeba vive um momento de tempo curto, mas intenso, com interferência direta e inclusive financeira decorrente da atividade de produção de gás. Tomando-se a noção de desenvolvimento qualificado pelo sentido socioambiental, configura-se este local como mundo rural dada a exploração econômica, a predominância de sociabilidade primária e a formação cultural marcadas por relação direta com a natureza (ALENCAR, 2003), com diferentes ruralidades (CARNEIRO, 1998; DURÁN, 1999; WANDERLEY, 2000; MOREIRA, 2002; CONCHEIRO, 2006; VEIGA, 2006).

As considerações teóricas e metodológicas elencadas fundamentam a opção pelo trabalho de campo, ouvindo pessoas que moram em Boipeba e que se encontravam na sua sede distrital (vila) chamada Velha Boipeba, independente de suas inserções institucionais; informantes inéditos, além das representações já conhecidas. Foram realizadas entrevistas não estruturadas e oficinas para apreender interações entre as atividades de pesca, turismo e exploração de gás; o levantamento de campo foi executado em dois momentos.

Primeiro, exploratório, durante dois dias em março de 2009, iniciando-se com o procedimento de caminhar observando e provocando conversas pela vila; abordamos então um menino, com pés descalços, que andava pela areia quente com outro menino e perguntamos onde ele estava indo. Ia catar ingá (fruta nativa) com o amigo; levou-nos à casa de um pescador onde, com outro pescador e uma funcionária da colônia de pesca, foi concedida a primeira entrevista não estruturada. Em janeiro de 2010, realizamos novas entrevistas, uma oficina com pescadores e uma com marisqueiras, tendo o turismo se revelado atividade relevante em termos de tensões socioculturais e com estreita vinculação às compensações ambientais decorrentes da exploração de gás. Se a demanda turística sofrera impacto com a pouca infraestrutura no abastecimento de água e luz, como ocorrera no ano novo de 2010, quando a ilha ficou sem abastecimento e lotada de turistas, mais impactantes socioambientalmente são as mudanças nas relações sociais que se estabeleceram a partir do turismo e da exploração de gás para a vida dos moradores antigos da Velha Boipeba, onde está situada a infraestrutura turística; configuraram-se tensões de ordem econômica, social, política e cultural.
Para responder à questão originalmente formulada, buscamos entender a natureza dessas tensões, o que atinge toda a ilha e não apenas a sede distrital. Para exposição da resposta, estruturamos o artigo examinando separadamente as atividades de produção material da população local após caracterização do lugar e finalizamos com a abertura de novas questões de pesquisa.

\section{Velha Boipeba sob regulação ambiental}

Chega-se a Velha Boipeba, sede de Boipeba, em pequenas embarcações que atracam na Praia de Boca da Barra, onde se reconhece a forte presença do turismo tanto pelo contínuo fluxo de pessoas que chegam e saem diariamente em diversos e alternados horários de lanchas rápidas e barcos quanto pela presença de pousadas e restaurantes. Embarcações de pescadores também compõem a paisagem, que vai se afirmando como turística à medida que se vai percorrendo a ilha e mais pousadas e restaurantes vão surgindo, além de casas com anúncio de aluguel escritos em português e em inglês, com números de telefone para contato, cujos prefixos de discagem indicam que seus proprietários não são moradores da ilha, mas de cidades como Rio de Janeiro, São Paulo, Salvador e outras do interior da Bahia. Estamos, portanto, numa ilha sem a insularidade (DIEGUES, 1998) que seu ambiente marinho sugere pelas paisagens ao longo do percurso que vai da cidade de Valença ou da localidade de Torrinhas até Boipeba. Por oposição à insularidade, vamos constatar ainda na Rua do Porto e na Praia de Boca da Barra a existência de lan house, indicando que a comunicação com o continente e alhures se dá não apenas pela movimentação das pessoas, mas também pela integração à dinâmica global do ciberespaço (MOREIRA, 2002; SANTOS, 2004; HASBAERT; PORTO-GONÇALVES, 2005; PEDRÃO, 2009).

A ilha integra a Área de Proteção Ambiental ${ }^{2}$ - APA Tinharé - Boipeba, criada pelo Decreto Estadual ${ }^{\circ} 1.240$, de 05/06/1992, com 43.300 ha, sem que isto se configure como um paradoxo diante das três principais atividades que dinamizam a economia local, a pesca, o turismo e a exploração de gás, tendo em vista que esta categoria de Unidade de Conservação - UC - prevê usos com disciplinamento estabelecido por zonas e gestão social sob responsabilidade governamental.

${ }^{2}$ A APA Tinharé - Boipeba é uma APA Estadual e, por isso, sob jurisdição da Secretaria de Meio Ambiente - SEMA. 
Para a SEMA, a importância da APA está no alto grau de preservação de seus ecossistemas, mantidos graças à relativa dificuldade de acesso às ilhas. [...] importante ecossistema estuarino, com manguezais que proporcionam um bom potencial pesqueiro, praias de rara beleza cênica, morros, recifes, barras, canais e ilhotas, extensas áreas de restingas, brejos e remanescentes de Mata Atlântica com fauna associada. [...] rico patrimônio histórico, datado dos primórdios da colonização portuguesa no Brasil; praias; passeios de barco; observação da fauna marinha; pesca artesanal (SEMA - Secretaria do Meio Ambiente do Estado da Bahia-Boipeba. Disponível em: $<$ http://www.semarh.ba.gov.br/conteudo.x?s=APATINH A\&p=APAAPA $>$. Acesso em: 09/08/2009, grifo meu).

A condição de APA, sendo um ordenamento que privilegia a relação direta com a natureza, afirma a localidade como mundo rural contemporâneo informado pela questão ambiental.

Esse rural se configura em plena interação com o mundo urbano, que transborda seu ritmo para um espaço geográfico e social cujo ritmo é dado pela dinâmica da natureza em suas atividades tradicionais e sua sociabilidade; portanto, uma natureza que, incluindo o ser humano, é culturalmente determinada (LENOBLE, 1969), onde interagem os tempos geofísicos e sociais ou humanos (FISCHER, 2008). O tempo humano não ilhéu, marcado pelo desenvolvimento urbano industrial tanto através da tecnologia industrial (gás, pesca e comunicação) que chega à ilha quanto pelo ritmo que o turismo imprime ao local pelos que têm ali um não-lugar (AUGÉ, 1994), perpassa as tensões examinadas entre pesca, turismo e exploração de gás. Coexistem os tempos humanos, urbano industrial e rural ilhéu. Em meio aos turistas que circulam pela ilha, nos deparamos com cenas de sociabilidade primária, como cumprimentos entre os transeuntes que evidenciam serem moradores nativos ou já ambientados ao lugar, pessoas em contemplação da natureza, mas também fila de espera de clientes turistas, nas barracas e lanchonetes que funcionam à noite na praça, ou ainda o uso de lanchas rápidas, que reduzem o tempo entre a ilha e o continente. Reconhecer a APA como mundo rural cujo ecossistema foi "mantido graças à relativa dificuldade de acesso às ilhas" não tem sido suficiente para equilibrar as mudanças de tempo e ritmo que chegam à ilha, a exemplo do mercado de terras induzido pela atividade turística, um paradoxo, dada a constituição da APA. Contudo, esse reconhecimento pos- sibilita dar visibilidade às identidades sociais da população para a qual a condição rural é morada da vida (HERÉDIA, 1979) e lugar de trabalho e vida (WANDERLEY, 2000) e que tem ficado invisível com a expansão metropolitana (ALENCAR, 2003, 2009).

Boipeba teve sua população contada pelo Instituto Brasileiro de Geografia e Estatística - IBGE - em 2007, totalizando uma população de 2.889 habitantes, sendo 1.195 homens e 1.391 mulheres, o que representa $21 \%$ da população total do município (13.712 habitantes); a população de Cairu em 2000 era de 11.410 habitantes, 39\% ocupando a zona rural e $61 \%$ ocupando áreas urbanas, tendo-se verificado, entre os anos de 1991-2000, um decréscimo de 3,18\% ao ano. Entretanto, os dados de 2007 apresentam uma reversão nesse perfil demográfico, em que, dos 13.712 habitantes, 1.096 são imigrantes, dos quais $83,8 \%$ originários do Estado da Bahia, contribuindo para variação da taxa de crescimento geométrico da população que, no período de 1991-2000, foi igual a $-3,02 \%$ e, no período, de 2000-2007, igual a 2,80\%. Examinando os dados populacionais, como populações urbana e rural, temos, segundo o IBGE, para os anos de 2000 e 2007, respectivamente: urbana, 6.961 e 7.680, com taxas de crescimento de $2,49 \%$ e $1,44 \%$, enquanto a rural foi de 4.429 e 6.032 , com taxas de crescimento de $-8,26 \%$ e $4,74 \%$, sugerindo predomínio de crescimento populacional no mundo rural, mesmo com taxa decrescente. Relativiza-se esse decréscimo pela classificação da população de Boipeba como urbana por ser a ilha um distrito do município.

Embora a classificação político-administrativa de Boibepa como distrito, tendo Velha Boipeba como sede distrital, torne sua população estatisticamente urbana e sua articulação em redes de comunicação e transporte a conecte com o município, a região, o estado e o resto do mundo, minimizando sua característica insular original, o modo de vida dado pelos ritmos dos eventos, pela sociabilidade primária e pelas atividades produtivas e sociais na relação direta com a natureza afirmam o espaço como mundo rural.

Como atividades produtivas tradicionais, o extrativismo pesqueiro se associa ao extrativismo e ao cultivo vegetal, como declaram pescadores entrevistados: “[...] alguns pescam, outros..." tem os que vivem de roça, e tem os que vivem de pesca "[...] tem, tem..." pessoas de vida rural, "[...] é... mas um de um lado outro de outro", indicando como rural tanto a atividade em terra quanto a atividade no mar. Ainda na fase exploratória da pesquisa, pescadores declararam em relação à vida na cidade que a vida em Boipeba 
[...] é um pouco, meio... graças a Deus, não tem violência. É... um lugar mais calmo... assim... e também coisas que a gente encontra na cidade que não encontra aqui, entendeu? A maior dificuldade da gente aqui é a locomoção. Ir pra Valença pra qualquer coisa, é muito caro a passagem (GRUPO FOCAL, 2009).

Por relatos obtidos junto a pescadores e marisqueiras, podemos inferir que esse modo de vida, que transforma a relação com a natureza em mundo ao invés de tê-la apenas como suporte, como o é para os demais animais (FREIRE, 1996), aparece tensionado pelo que deveria ser a proteção ao ambiente natural, comprometendo a reprodução social rural em Boipeba. Para moradores tradicionais da ilha sobreviverem, mantendo relação direta com a natureza para além da pesca, eles declaram que:

Aqui não pode plantar; eu fui botar uma rocinha pra plantar uns aipins pros netos, tem neto que só o mundo, o fiscal da prefeitura chegou e mandou parar com a rocinha... não pode plantar no cimento! [...]

Eles não querem que desmate e aquilo ali primeiro tem que desmatar pra poder plantar. Quem tem o direito de desmatar é a Alfaville da Perini; está aí tudo desmatado, eles não viram nada [...] e está lá tudo desmatado, só eles que podem desmatar Boipeba. Antes plantava tudo direitinho, mas agora só quem pode desmatar é a Perini. A gente não pode tirar uma vara, mas eles tiraram 350 pra fazer festa, pra isso, pra aquilo. [...] somos "pequeninhos" não podemos. Eles dizem aqui é APA. APA significa o que? Área de Preservação Ambiental, então pra a gente pequeninho não pode fazer isso, mas o grande vai lá e faz. Entendeu? [...] tudo começou com a APA (OFICINA, 2010).

As matas de Boipeba já foram alvo de controle ambiental no século XVIII, menciona Flexor (2004), a título de curiosidade, considerando ser o Baixo Sul da Bahia "uma das regiões de maior diversidade ambiental e paisagísticas do planeta":

[...] em meados do século XVIII, era tão intenso o corte de árvores para construção naval e construção civil na
Capital, a ponto de o então Juiz Corregedor das Matas sustar, por prazo indeterminado, o abate de árvores nas ilhas que compõem o atual município de Cairu. Essa medida teve longo alcance, permitindo a regeneração espontânea da cobertura na ilhas de Tinharé e Boipeba (FLEXOR, 2004, p. 32).

As duas situações históricas se assemelham apenas no objeto do controle sobre as matas, mas diferem radicalmente em termos de uso da área desmatada e da condição econômica dos agentes do desmatamento sob pressão das normas legais, o que configura essas relações diretas com a natureza como historicamente construídas e, portanto, condicionadas por experiências concretas de produção material e social. Ainda apoiada em Flexor (2004), mas também por dedução a partir do uso dado às madeiras retiradas da mata, é possível afirmar que a prática do desmatamento não era um costume dos índios que habitavam a região, haja vista a afirmação de Baltazar da Silva Lisboa, que era o conservador das matas e ouvidor da Comarca de Ilhéus, no final do século XVIII, de que:

Os portugueses que com eles (índios) vivem longe de os instruírem e civilizarem, foram os que lhes introduziram muitos vícios que não tinham: eles se ocupam em tirar madeiras, e plantar mandioca e café, estando as matas de construção de que se enriqueciam destruídas nas suas margens (dos rios) légua e meia e em parte duas e três (FLEXOR, 2004, p. 45).

Nessa época, precisamente 1799, é que a Corte portuguesa, com D. Maria I, cria o regimento para os cortes de madeira, contexto em que demarca "terras devolutas que não poderiam ser convertidas em sesmarias", seguindo daí reações contrárias, ajustes, que tornam esses processos completamente atuais em termos de tensões entre sociedade e natureza ${ }^{3}$. Gestão de Unidades de Conservação, a exemplo de APA, como referido anteriormente, ou mesmo as alterações do Código Florestal em tramitação na Câmara Federal, são ilustrativas da contemporaneidade dessas questões. Contudo, as contingências atuais tornam proibido o que era permitido.

\footnotetext{
${ }^{3}$ Para informações detalhadas, ver Flexor (2004).
} 
Um documento de 1783 falava ainda no subaproveitamento da agricultura, especialmente nas melhores léguas de terras que tinham sido dos jesuítas, na Barra de Boipeba até o Rio de Contas, onde os religiosos tinham instalado colonos rendeiros, ou escravos, permitindo apenas que cultivassem a "mandiba" (mandioca), não possibilitando que fizessem outras benfeitorias. Em consequência, esses moradores, em sua maioria, viviam da pesca e da caça "à maneira dos índios" (FLEXOR, 2004, p. 57).

[...] a natureza do terreno não favoreceu a plantação de mandioca em Boipeba... (FLEXOR, 2004, p. 60).

Essas breves notícias da história social de Boipeba, uma das "regiões de mais antiga colonização do Brasil" (FLEXOR, 2004), examinadas a partir da vigente Constituição Brasileira de 1988, dão pistas da diversidade de questões sociais, econômicas e ambientais que perpassam o cotidiano dos seus moradores; na ilha é possível constatar a existência de comunidades tradicionais diversas, como uma já reconhecida comunidade quilombola, mas também extrativistas do mar. A dinâmica da ilha é ilustrativa do desenvolvimento como compreendido em a "nova des-ordem mundial" por Haesbaert e Porto-Gonçalves (2006).

Contemporaneamente, acrescem-se as atividades de turismo e prospecção de gás a esse panorama social e histórico, trazendo outras problemáticas decorrentes das regulações ambientais, a exemplo do uso dos recursos financeiros. A compensação de que trata o art. 36 da Lei 9.985/2000 e todo o capítulo VIII do dec. 4.340/2002 art. 31 e seguintes - tem cálculo específico, não pode ser inferior a meio por cento dos custos e vai para o poder público com fins específicos. Na esfera estadual, temos a Lei 10.431/2006, regulamentada pelo Dec 11.235/2008, que contempla o assunto na seção $\mathrm{V}$ - art. 213 e seguintes, em caráter compensatório aos impactos socioambientais gerados. Os recursos provenientes da compensação, para Boipeba, de medidas mitigadoras ou compensatórias previstas no EIA/RIMA, têm sido utilizados pela ONG AMABO (Associação de Moradores e Amigos de Boipeba). Não será problematizado aqui o caráter efetivamente compensatório ou mitigador das intervenções: serão apenas identificadas tensões decorrentes dessas novas atividades. Assim, na fase exploratória da pesquisa, fomos informados, em entrevista em grupo, que o dinheiro previsto no projeto de compensação para implantação da rede de esgoto havia sido liberado, mas:
O esgoto das casas, 80 casas. [...] fez nas outras ilhas. [...] só aqui e em Moreré são 80 casas. Aí rolou, rolou [...] o pessoal só faz assinar papel e nada de vir [...] disse que vinha no fim do ano [...] o dinheiro já tem uns 3 anos na Caixa Econômica. Aí fez em Torrinhas, fez em Cairu, em Gamboa [...] só que aqui, em Moreré e Cova da Onça [...] o dinheiro tá rolando na Prefeitura. [...] Nenhum bloco botaram aqui [...] fizeram uma reunião, na análise deles não podia escoar o esgoto [...] Local pra fazer uma rede de tratamento de esgoto tem. O problema é que eles não querem gastar. $\mathrm{O}$ dinheiro já está aí. $\mathrm{O}$ que eles não querem é gastar. [...] Porque o dinheiro já tá aí. A Petrobrás já liberou o dinheiro e parou aí e pronto, acabou (GF, 2009).

As institucionalidades que incidem sobre a dinâmica da ilha de Boipeba interferem na atividade pesqueira, tanto na contingência de ser um espaço sob impacto ambiental quanto na estruturação do espaço como protegido, tendo em vista que o uso comum da natureza como população extrativista tradicional fica restringido às regulações da Unidade de Conservação e do Plano Diretor de Desenvolvimento do Município, que instauram conflito de competência entre governos estadual e municipal. Assim, a restrição da propriedade da terra a $250 \mathrm{~m}^{2}$ prevista no Zoneamento Ecológico Econômico - ZEE - do Plano de Manejo da APA - § $1^{\circ}$ do art. 15 - confronta com o PDDU (art. 22, VII e Anexo I) do município, que divide a zona urbana de Boipeba em Zona Urbana Consolidada - ZUC e Zona Turística - ZT, com limitação de área mínima de lote em $300 \mathrm{~m}^{2}$ para ZUC e 1.500 ha para ZT. Em que pese a supremacia legal do estado sobre o município, o conflito estabelecido entre os tamanhos da propriedade fundiária pela APA (estadual) e pelo PDDU (município) subverte a efetividade dessas competências, já que a administração municipal é mais presente na região (visto no item anterior deste artigo), ao tempo em que a APA supostamente constituída com gestão participativa é desconhecida dos pescadores.

[...] tem uma série de problemas, essa APA. Por exemplo, a ZUC - Zona de Urbanização Controlada... o lote mínimo da APA é $250 \mathrm{~m}^{2}$, o lote mínimo pela prefeitura é de $300 . .$. [...] os filhos do nativo pobre não vão ter mais moradia aqui na ilha. Porque hoje eles não vão mais poder comprar um terreno aqui pra fazer uma casa $[\ldots]$ porque tem um negócio aí... acho que é essa tal de APA aí mesmo... diz que só pode comprar a partir de $300 \mathrm{~m}^{2}$ 
e pra mim a prefeitura está começando a expulsar os nativos daqui. [...] é... e essa geração que tá crescendo e que não vai sair daqui mesmo, como é que faz pra comprar $300 \mathrm{~m}^{2}$ como eles tão dizendo que custa o que? 25, 30 mil, 40 mil, cinquenta... quem é que tem esse dinheiro? Aí eu não posso comprar, aquele ali não pode comprar. [...] hoje quem tem, pronto; quem não tem, não vai ter, porque a prefeitura não dá condição, nem os dono de terra também dão condição, porque tem uma lei ambiental que diz que só $300 \mathrm{~m}^{2}$ de terra. [...] Quem tiver filho, vai morar todo mundo dentro de casa, todo mundo na mesma casa, entupindo ali... ou vai expulsar... (EI 1, 2010).

Do que se apreende, a proteção ao meio ambiente tende a se configurar como mecanismo de exclusão social no sentido radical de não possibilitar o pertencer a determinada sociedade diante da impossibilidade de inserção como consumidor na mercantilização da terra e dos demais elementos da natureza. O que se vislumbra é a reprodução dos mesmos processos de favelização e de expropriação verificados com a chegada do turismo e da urbanização em outras áreas de pesca, a exemplo de Salvador e Itaparica, bem como em Morro de São Paulo, na mesma APA Tinharé - Boipeba.

A dimensão institucional se revela como lócus de conflitos de competência e de interesses (MOREIRA; GAVIRIA, 2002) entre gestores e público alvo das ações compensatórias, produzindo tensões que envolvem não apenas a gestão do recurso, mas também segregações sociais decorrentes da articulação entre turismo e ação compensatória. Essa articulação se dá através da associação que opera a mediação entre empresas de exploração de gás e população impactada, a qual se expressa com indignação: "A associação tem presidente $[. .$.$] tem secretário [...] tem$ tudo só não faz nada. [...] não resolve nada. Botando no liquidificador não vale um" (GF 2009).

Em 2010, outros informantes repetem a indignação:

[...] essa associação de moradores [...] Eu tive oportunidade de participar de uma eleição dessa associação. $\mathrm{E}$ apenas cinco membros têm direito a votar. E teve um que teve que votar por telefone. Eu tava lá, ninguém me contou, eu vi. (Risos). Essa associação [...] é a mais velha, eu não sei quantos anos. [...] E a vida [...] presidente só ele. E não é brasileiro. Quanto mais boipebano. [...] o problema é o estatuto (OFICINA 1,2010).
Entrevistados informam que existem dez associações, a maioria delas criada após a chegada da Petrobrás, como representação da comunidade constituída juridicamente para operacionalizar a mitigação ou compensação ambiental à comunidade local, conforme o EIA/RIMA. Esse quadro formal de dez associações instituídas sugere que a comunidade está organizada como sociedade civil. Entretanto, um dos entrevistados reage.

Desculpa, eu discordo! Só olhando de fora. Só superficial.

[...] Mas na verdade, eu the dou o segredo, na verdade o que motivou o nascimento dessas organizações foi a presença da Petrobrás que chegou com a conversa estranha... [...] Uma já existia que é AMABO, certo? Chegou com a conversa estranha que ia sair dinheiro, mas não sai para você não, que é pessoa física... pras associações fizeram, fizeram, fizeram... é isso aí minha "cumade"... [...] Mas sabe, quando se parte realmente pra discutir os problemas da comunidade não há união, não há associações... eles se divergem, há um desinteresse profundo. [...] Tem exceções, a Associação de Mulheres a gente vê aí... a própria $\mathrm{AMABO}$ que por ela ser a mais velha daqui, ela tem um contrato com a Petrobrás sobre reciclagem de lixo, que eu tenho lá minhas interrogações, certo? [...] Porque princípio, meio e fim e eu não vi um fim claro, certo? [...] Agora, tem associações que funcionam... tem a Luz Cultural que tem ali uma biblioteca pública, que isso é um fato, a gente não vai negar, mas as demais... só conversa mole (EI 1, 2010).

Segundo o relatório El Paso \& Soma (2007), quando de uma reunião com as mulheres da ABMMVB - Associação Beneficente das Mulheres e Marisqueiras da Velha Boipeba, que em 2007 contava com 210 associadas e priorizavam a busca de alternativas de renda e complemento da renda familiar, apenas uma mulher compareceu à reunião solicitada pela empresa de consultoria. No contexto da representação institucional, o fortalecimento da identidade ambiental e a participação da comunidade nas discussões sobre os impactos positivos e negativos das atividades petrolíferas na região ficam comprometidos diante do quadro de falta de legitimidade institucional estabelecido "em nome" da população de Boipeba por intermédio das associações.

Como ilustra o depoimento a seguir, a fragilidade de coesão social em Boipeba se expressou fora da atividade produtiva, na produção social da vida dos pescadores. 
[...] eles se ajudam na atividade da pesca [...] Mas aqui (em terra) já é mais cada um por si [...] embarcado é porque a capitania exige, se não ajudar o que tá lá precisando de ajuda, aí dá queixa. [...] pra tirar carteira tem que fazer curso [...] e se não ajudar, quando chegar aqui em terra, chega lá e fala pra capitania (GF, 2009).

A dificuldade em atuar de forma organizada adviria, segundo esse grupo focal pela ascendência de um vereador:

Se o vereador falar, tá falado. [...] é isso, é como chegou a senhora aí, né? Aí bota no ar. Aí reúne... pescador vai. Aí, vamos dizer assim, né? Chegou uma professora, aí... vamos lá ouvir, pra ver o que interessa [para] a gente. Faz aquela reunião, todo mundo vai ouvir. Depois que a senhora for embora, pronto. Ninguém fala mais naquilo ali. [...] muitos até querem fazer alguma coisa pelo lugar, mas já outros... não querem. Aí, não tem apoio, aí, como é que vai fazer? (GF, 2009).

Do que se apreende, torna-se necessário uma pesquisa especificamente voltada à compreensão desse fenômeno (des)organizativo que parece ter sido acirrado com a ingerência dos agentes ambientais desde os EIA/RIMA e chegando com reforço de assimetrias à intervenção para compensação ambiental.

\section{A pesca artesanal na produção material e social da vida}

A atividade pesqueira em Boipeba é praticada com tecnologia artesanal e envolve a pesca desembarcada, a pesca embarcada e a mariscagem, detalhadamente caracterizadas através do Diagnóstico Rápido Participativo já mencionado, e sua relevância é reconhecida pelo órgão ambiental e pelas empresas envolvidas com a exploração de gás, como ilustra o trecho abaixo, que introduz o projeto de compensação exigido pela legislação ambiental.

O projeto desenvolvido, apresentado e aprovado segue a orientação do Órgão Licenciador com relação à compensação para a atividade pesqueira, que fixa a seguinte diretriz: “... a proposição do Plano de Compensação é a de fomentar projetos locais voltados para o uso sustentável dos recursos pesqueiros, incluindo ações

\begin{abstract}
definidas em conjunto com as comunidades pesqueiras afetadas, levando em consideração suas necessidades, visando capacitá-las, de forma a possibilitar sua participação efetiva na gestão dos recursos ambientais $\boldsymbol{e}$ pesqueiros da região" (grifo nosso). Tal diretriz ocorre pelo fato de a atividade de perfuração ocorrer em áreas rasas e sensíveis, onde a atividade de pesca artesanal é intensa. [...] dois principais objetivos para o projeto de compensação: (i) iniciar um processo de cogestão pesqueiro a partir de dinâmicas e metodologias participativas nas comunidades que operam na área de influência direta imediata do empreendimento; (ii) compensar as comunidades pesqueiras devido aos impactos e interferências relativos à atividade de perfuração no Bloco BM-CAL-4 (E1 PASO \& SOMA, 2007, p. 1) (os grifos são do documento original).
\end{abstract}

Boipeba se insere na área de abrangência impactada pelo "fato de a atividade de perfuração ocorrer em áreas rasas e sensíveis, onde a atividade de pesca artesanal é intensa", e a Petrobrás atuaria junto às comunidades pesqueiras "visando capacitá-las, de forma a possibilitar sua participação efetiva". Entretanto, como visto no item Velha Boipeba, a institucionalização das relações sociais como resposta a essa intervenção e, como veremos adiante, absorvidas por essa intervenção associada à externalidade em que se constitui o turismo, agravou a fragilidade do potencial participativo que se supunha existir como tradicionalmente vivenciado no mundo rural em forma de mutirão e ajuda mútua. O diagnóstico da El Paso \& Soma (2007) que deu suporte à intervenção sugere a existência anterior de associações formais, embora predomine informalidade. "[...] sobre a representatividade, não foi coletada informação das entidades de classe para $52 \%$ dos participantes. [...] demais, todos [...] pertencem à Colônia de Valença, havendo ainda a filiação nas Associações dos Pescadores e das Marisqueiras (não estimado)" (EL PASO \& SOMA, 2007, p. 376).

Há muita informalidade na comunidade pesqueira de Boipeba, segundo estimativas dos próprios pescadores existem uns $20 \%$ em Boipeba que não possuem nenhuma embarcação. [...] pescadores locais para estratificar a comunidade [...] Melhor de Vida: Comércio, Pousada, barco e casa própria (15 a 16 pessoas); Média: Aposentado; Pior: Diarista (pesca, roça); Muito Pior: Muitos filhos e que vivem do mangue (bairros do Areial, Tiririca, Moreré/Monte Alegre) (EL PASO \& SOMA, 2007, p. 376). 
Na condição de informalidade como qualificada nesse diagnóstico (não possui embarcação), consideramos mais relevante a assimetria social entre os pescadores. Ademais, é historicamente relevante a constatação de que pesca e mariscagem estão sempre associadas a outras atividades mais ou menos monetarizadas, geradoras de rendas agrícolas e não agrícolas. O lado mais frágil dessa assimetria diz respeito àqueles que associam pesca e mariscagem ao pequeno cultivo de alimentos que, como vimos anteriormente, segundo depoimento de pescadores nativos, deixou de ser praticado por proibição ambiental. As desigualdades sociais e não a informalidade, em Boipeba, em torno da atividade pesqueira, foram evidenciadas desde a fase exploratória da pesquisa, quando nos foi informado que os pescadores locais têm carteira profissional da Capitania dos Portos e são registrados na Colônia de Pescas que é sediada em Cairu, portanto, formalizados, o que não tem sido suficiente para terem acesso aos benefícios compensatórios para a atividade pesqueira, se sobrepondo o critério de estar associado ao de estar efetivamente em atividade.

Quem "tava" associado e não era pescador, ganhou! Mulher, até adolescente que nunca foi na maré ganhou. [...] Aqui você pode ser um bancário, se associou, se vim alguma coisa, eles preferem dar pra você do que dar pro pescador. [...] A maioria das pessoas da associação que é pescador saiu da associação, porque não valia a pena. [...] Tem a Colônia. Só que o pessoal não acredita muito na colônia. O problema todo é esse. A colônia foi que trouxe a sede daqui, arranjou dinheiro pra fazer a sede da associação, mas até hoje se for botar qualquer coisa pra beneficio da colônia e da associação, ninguém quer. [...] as marisqueiras... a maioria está aposentada [...] Se não está tendo pescado, pra ir lá e sustentar a família [...] Hoje em dia... o trabalho... pra homem... preferem trabalhar mais em terra do que pescar. [...] A maioria quando emprega, não assina a carteira, não paga tempo. Aí eles paga a colônia pra poder se garantir no futuro (OFICINA 1, 2010).

A relação dos pescadores com o espaço de terra da ilha se reproduz, em termos de "uso sem cercas" para o extrativismo vegetal, também no espaço do mar, numa referência ao mar como "de todos". Nesse sentido constatamos, durante o trabalho de campo, que a comunidade pesqueira de Boipeba não se apropria territorialmente do local de pesca, ou seja, não demarca os pesqueiros locais como locais a serem utilizados pelos pescadores locais. A área recebe com frequência embarcações "de guincho", vindas de outras localidades e que realizam um tipo de pesca predatória - $\mathrm{o}$ arrastão, causando a degradação do ambiente físico e a redução do pescado. Este fato é reconhecido em estudos e diagnósticos como os realizados pela Petrobrás e pela empresa El Paso e foi aferido como uma unanimidade através dos questionários aplicados junto aos pescadores de Boipeba ${ }^{4}$; reproduz-se na escala local o conteúdo de poder das tecnologias nas relações sociais (HAESBASERT; PORTO-GONÇALVES, 2005), acirrando desigualdades. Assim é que a pesca, antes principal atividade econômica da localidade, hoje sofre um decréscimo até mesmo para o consumo local, "[...] o pescado aqui diminuiu e muito. Fracassou muito esse negócio de pescaria aqui. Era muito peixe camarão, essas coisas [...] essa geladeira [...] mesmo, só vivia cheia [...] era cada camarão grande! [...] os barcos grandes, vêm de fora, acaba com tudo aqui [...]" (GF 1, 2010).

A percepção da atividade pesqueira como uma arte de livre acesso à natureza, própria de comunidades tradicionais que se reproduzem não só economicamente como socioculturalmente nesse sistema de produção, embora em contradição à propriedade privada nas sociedades capitalistas coexistindo com democratização por regulações, legitima-se no Brasil a partir da Constituição Federal de 1988, quando do estabelecimento de direito de propriedade a índios e quilombolas. A contradição entre direito de propriedade capitalista e de acesso à natureza se soma, neste caso, às decorrentes da sobrepesca e da pesca predatória, estando os pescadores e marisqueiras locais que não detêm tecnologia de pesca industrial submetidos ao fato de que a pesca tem suas especificidades, como a sazonalidade e a mobilidade. Para as marisqueiras, mulheres que pescam no mangue,

[...] "Nem camarão nem peixe dão mais como antigamente. Caranguejo nem se fala, acabou mesmo. E eu, que criei meus 12 filhos com caranguejo!" [...]

\footnotetext{
${ }^{4}$ Referem-se à coleta de dados para elaboração, no âmbito desta pesquisa, da dissertação de Jeísa Crusoé no Mestrado Profissional em Planejamento Ambiental, da Universidade Católica do Salvador, sob orientação desta autora.
} 
mortandade de caranguejos, em 2003, como um grande impacto para a renda familiar. "E teve uma época que até siri tava morto no mangue." (EL PASO \& SOMA, 2007, p. 380).

[...] partiram para a pescaria da lambreta; quando esgotou a lambreta, partiram para o aratu. [...] A mortandade do caranguejo causou um problema no ecossistema como um todo, afetando também os outros recursos dos quais dependem (EL PASO \& SOMA, 2007, p. 384).

$\mathrm{Na}$ oficina realizada com pescadores se constatou que a chegada da Petrobrás também contribuiu para a redução do pescado, tendo em vista ter-se instalado em área de pesqueiro, como ilustra o depoimento: "A pesca diminuiu. [...] Quando a Petrobrás chegou... onde ela está instalada é pesqueiro, se fazia pescaria" (OFICINA 1, 2010). Além disso, a desigualdade de condições de sobrevivência na atividade pesqueira se acirra em assimetrias na integração dos circuitos de produção e comercialização do pescado, em mercado monopolista com concentração em um intermediário na compra de peixe localizado no município de Valença.

[...] tem pouco mesmo [refere-se a dois compradores]. [...] Entrega aqui mesmo, em restaurante, barraca; eles cobram barato. Vender pra Fulano e pra lá? Só o camarão. É com certeza [o maior comprador daqui]. [...] Hoje até ele não está dominando muito porque os barcos ele vendeu quase todos. Porque o pessoal aqui sai todo pra trabalhar pra Fulano; hoje ele é policial [...] mas não deixou a pesca, [...] ele tem frigorífico em Itacaré [...] [os barcos] ele levou pra lá [...] uma frota de quase uns 20 barcos. No verão [...] bem poucas pessoas que pescam [...] só vai mesmo o pescador mais velho que nem eu e... os mais novos não querem pescar [...] o pescador vai pra lá, se matar de trabalhar... aqui eles vende a 10 , 12 reais o quilo do peixe no verão. $\mathrm{O}$ pescador, ganha 3 conto [reais] por quilo. Por isso que muita gente não quer ir pescar... porque quem ganha é o dono de barraca, o dono do barco (GF, 2009).

Pesca e turismo se tensionam na vida dos pescadores artesanais, que no inverno precisam armazenar o camarão para o verão, mas que não têm fábrica de gelo (solicitada no projeto de compensação) nem frigorífico, impossibilitando a formação de estoques.
[...] o camarão é todo entregue a Fulano [...] então, a fábrica de gelo era pra isso [...] sim porque, agora em abril vai entrar a proibição do camarão. Aí não pode arrastar pra pegar [...] dá pra armazenar [...] a proibição do camarão vai de abril até 30 de maio. Não, não. Até 15 de maio. [...] só problema de você ir buscar lá em Valença... trazer, pra você ir pescar... aí a despesa fica um pouco alta, não compensa. [...] terreno pra botar a fábrica de gelo aqui é o que não falta. $\mathrm{O}$ problema era o dinheiro. Já que era 30 mil que ia dar, mas $30 \mathrm{mil}$ não dá pra fazer porque tem que comprar o maquinário (GF, 2009).

Nesse quadro de assimetrias, os benefícios aos pescadores decorrentes da compensação e da atividade de exploração chegam ao público-alvo reproduzindo as desigualdades sociais a partir do critério de eficácia econômica da intervenção, quando o uso do recurso é produtivo, e do critério de carência absoluta, quando o uso é social. Assim, há opiniões de que os benefícios levados pela Petrobrás à população pesqueira, serviriam

Só pra prefeitura. [...] esse cheque solidário era para os pescadores, aí tem gente que nem pescador é, nunca nem foi na beira da maré, ganha. Aqui mesmo, uma mulher não pode ganhar porque disseram que tinha condições e aí não podia ganhar. [...] Se a Petrobrás deu bolsa pros pescadores é pros pescadores, não tinha nada a ver se tinha condições ou não (GF, 2009).

O estabelecimento de critérios econômicos para definição de público-alvo de benefícios de política tem sido problematizado nos programas de desenvolvimento rural dirigidos a agricultores familiares por deixarem à margem milhares de famílias rurais. Contudo, não são programas compensatórios e sim de investimento, como o Programa Nacional de Apoio à Agricultura Familiar - PRONAF, ainda assim merecedores de ajustes de política. No examinado, o que está sendo objetivado é a compensação por impactos decorrentes de investimentos de alta monta sobre a base de reprodução material e social da vida de uma população de pescadores tradicionais, o que torna mais questionável a linha de corte da população efetivamente beneficiada; acresce-se a escolha do uso coletivo a ser feito com os recursos. Segundo o mesmo grupo de entrevistados, 
[...] fizeram um Centro Cultural... se você tem cultura, mas não tem o que comer... vai pra que lugar isso aí? Pra lugar nenhum... que adianta cultura se você não tem uma alimentação boa ou qualquer coisa assim [...] Esse negócio de jogar capoeira... capoeira não enche barriga de ninguém, [...] tem que ver a prioridade. [...] Cultura e diversão. E o resto das coisas, fica onde? Eles querem fazer isso pra turista, porque no verão aqui enche de turista. Aqui turista manda... se você tiver qualquer coisinha aí, ligar um sonzinho e o turista vir e dizer que tá incomodado, a polícia vem e prende seu aparelho de som. [...] no verão, turista é quem manda (GF, 2009).

Apreende-se entre as atividades de pesca artesanal (comunidade tradicional) e turismo (empresários e estado) uma clara tensão que põe em disputa a produção material e a produção social da vida, ao mercantilizar manifestações culturais próprias do cotidiano da população da ilha ao tempo em que desativa nesse mesmo cotidiano a produção material que garante a reprodução social dos pescadores. Desloca sua identidade social contemporânea para a manutenção de manifestações da tradição cultural como elemento identitário. A produção material fica subordinada ao turismo enquanto produção social pela mercantilização da cultura e fica subsumida também ao turismo, que passa a dar a dinâmica do mercado local sob diretriz e financiamento de políticas de desenvolvimento econômico e de regulação ambiental, num mercado capitalista sob constrangimentos ambientais. Assim é que, no verão, os pescadores de Boipeba, trabalhadores do setor primário da economia, metamorfoseiam-se em trabalhadores do setor terciário, o de serviços, quiçá do setor secundário, o da indústria (turística), tornando indissociáveis quaisquer intervenções socioambientais, escalas e sentidos do desenvolvimento.

\section{O turismo entre a dinâmica rural local e o gás}

Apoiado em Muricy (2009), é possível afirmar que na década de 1960 entendia-se o turismo como melhor alternativa para o desenvolvimento de países então denominados de Terceiro Mundo, por não requerer altos investimentos em infraestrutura e por possibilitar o dinamismo econômico, aquecendo setores como construção civil, imobiliário e de entretenimento. A visão do turismo como "indústria limpa”, que não provocava alterações ambientais, passa a dar lugar à compreensão de que a atividade provoca, sim, transformações várias e requer senso de sustentabilidade que fundamente um novo modelo.

$\mathrm{O}$ interesse das pessoas pela natureza faz com que espaços com ecossistemas mais preservados ou com características inerentes ou propícias para seleção de Unidade de Conservação sejam os mais requisitados para visitação. Como afirma Muricy (2009), citando Reinaldo Dias, em sociologia do turismo "o maior interesse pela natureza está se convertendo na principal motivação para sua destruição" (MURICY, 2009, p. 47). A destruição da natureza, em Boipeba, tem sido acompanhada das transformações das relações que configuraram como insular o mundo dessa população. A dinâmica que a atividade turística implantou em Boipeba a retirou da insularidade que preservou seu ecossistema. "Atualmente (Boipeba) vem se destacando como ponto turístico, o que vem gerando crescimento da comunidade em bairros onde antes havia mata atlântica, roças e plantações. Bairros como da Tiririca e Matança são um exemplo" (EL PASO \& SOMA, 2007, p,. 374).

Na perspectiva do Plano de Desenvolvimento Integrado do Turismo Sustentável (2004), o Governo do Estado compreende que a atividade turística poderá contribuir com a economia local de três maneiras distintas: i) acrescentando renda e emprego para os habitantes; ii) aumentando o mercado consumidor dos produtos da região através do fluxo de visitantes; e iii) colaborando com a melhoria das condições de acesso e distribuição da produção local (BAHIA, 2004, p. 33). Em termos de categoria ambiental, o mesmo documento classifica o município em "Municípios com Pressão Antrópica Muito Alta com Degradação Urbana e dos Recursos Hídricos" (BAHIA, 2004, p. 99) e, por fim, define que o município tem "porte econômico pequeno (dentro do contexto do Polo) e atividade turística significativa para a economia municipal" o que justifica "investimentos direcionados à consolidação da atividade e prevenção de impactos” (BAHIA, 2004, p. 135).

Como decorrência da dinâmica própria do desenvolvimento em sociedade capitalista, os investimentos nessa atividade também acirraram desigualdades, combinando atividades intersetoriais e relações sociais de produção capitalistas e não capitalistas sob a égide da concepção institucional de sociedade, que desloca para a gestão social em organizações formais as condições de possibilidade de democratização e equidade. Como já mencionado, em Boipeba apenas 15 a 16 pescadores estão em condição de "Melhor de Vida" por possuírem comércio, pousada, barco e casa própria; o turismo, na articulação com a pesca, interage no mercado em termos de oferta e preço do pescado, 
[...] pela procura do mercado, que varia bastante de inverno a verão, principalmente nos preços praticados aos peixes de $1^{\mathrm{a}} \mathrm{e}$ ao camarão, por causa do turismo, como também pela capacidade de estocagem dos recursos, até então mais restrita aos compradores existentes da comunidade. A cavala e o dourado, por exemplo, são peixes que dão muita produção no verão (água clara), época em que o pescador vende muito, seja para o atravessador, ou, por conta própria, diretamente a pousadas e restaurantes, obtendo preços melhores. Já no inverno, a possibilidade de atender ao mercado com esses recursos é exclusividade dos atravessadores. Já o camarão-rosa, embora não dê quase nada de produção no mar em janeiro, é quando se obtém maior renda, por causa do turismo (EL PASO \& SOMA, 2007, p. 378).

A integração entre turismo e pesca tensiona não apenas o nível dos preços, mas também a regulação ambiental para a atividade pesqueira; por exemplo, os períodos de defeso do camarão situam-se exatamente no período de alta estação turística, até $1^{\circ}$ de abril.

É proibido, é proibido. Agora tem gente que vai escondido [...] pode [pescar peixe] mas, não tem peixe [...] é bem pouco barco que vai [...] no inverno é que eles não vão pescar lá fora [...] quase ninguém pesca mesmo. Porque o defeso aí foi do camarão. E a gente precisa é do camarão... Camarão ninguém pega [...] não tem o camarão pra fazer isca. aqui ganha no verão pra gastar no inverno (GF, 2009).

Embora não seja objeto específico desta pesquisa examinar atividades de cultivo e extrativismo vegetal nesse conjunto de tensões, o modo de vida rural é o que organiza a reprodução social dos pescadores artesanais de Boipeba. Importa frisar que como vida rural sua reprodução material supõe a realização de múltiplas atividades, monetarizadas ou não, que integram sua pauta de produção sazonal, gerando renda agrícola e não agrícola.

Aqui tem muita mangaba... caju [...] o pessoal cata muito caju pra fazer suco, fazer polpa, essas coisas, a mangaba, manga, que dá lama, tem jaca [...] planta melancia, abacaxi [...] mas tudo que sai daqui, a gente compra mais caro do que se comprar lá fora [moradores daqui] [...] E se a gente compra aqui é mais caro do que lá fora [...] eles vendem pras pousadas, pros moradores eles não fazem nem questão de vender (GF, 2009).
Como se pode observar das informações até aqui elencadas, a produção material e social da vida em Boipeba, para a maioria da sua população, está estruturada na relação direta com a natureza. Neste contexto, a atividade turística em Boipeba, para que ocorra em um padrão de desenvolvimento integrado e sustentável, deve considerar a "preservação da espécie humana" que, ao longo de pelo menos 500 anos, periodizando-se com o processo de colonização, fez daquela ilha um espaço de interesse desenvolvimentista. Assiste-se, contudo, a um processo de expropriação das condições de reprodução social da maioria dos nativos que ali permanecem ou que retornaram da emigração, motivados por expectativas diante das melhorias infraestruturais e que foram fortemente condicionadas ao surgimento da atividade turística. A expropriação é acompanhada do crescimento econômico da minoria que, por deter algum capital inicial, integrou-se à atividade turística.

Identificamos por meio de depoimentos, ainda na fase exploratória da pesquisa, que as mudanças que culminam com a intensificação da presença de visitantes a Boipeba e, aos poucos, do turismo como atividade econômica, datam de uma década, com a chegada da luz elétrica e da água encanada. A chegada da água pela Empresa Baiana de Saneamento - EMBASA - não é muito compreendida pela população "nativa" por implicar em pagamento pelos consumidores, mesmo sendo água tratada, já que a água é da própria localidade, como se depreende do depoimento a seguir, sobre se a água, na ilha, é da EMBASA:

[...] da EMBASA o que criatura? Se o poço é daqui. Eles só fazem puxar e distribuir [...] trata [...] é muito caro a água aqui. [...] antes não pagava, mas tinha água encanada. Só que faltava... agora não falta assim. Agora, no verão fica água lá embaixo pra pousada e aqui... só cai de manhã cedo.... e a gente paga o mesmo preço. Não tem essa. No verão, a prioridade é pras pousadas. [...] a gente paga o mesmo preço e fica sem o fornecimento. [...] o rapaz falou que ali tem 160 mil litros por hora [...] então agora vai ter como não faltar água pra gente (GF, 2009).

Esse depoimento traz mais uma nuance das tensões decorrentes da contradição entre o surgimento de melhorias e a quem elas servem como alvo. Acrescentam-se tensões de ordem material a outras, de ordem imaterial, diante da presença de outro jeito de viver, de como essas pessoas veem e como são vistas nas relações que estabelecem. Entre pescadores e marisqueiras, registra-se a percepção de que 
"a maior parte dos que vem pra cá só trazem pesadelo para aqui"; muda a qualidade das relações, do momento em que chegam os de fora para se instalar, quando o nativo ou morador estabelecido é considerado importante, para o momento em que, já estando instalados, os de fora secundarizam ou até hostilizam os estabelecidos, que, não dispondo de acumulação inicial de capital, ficam subalternizados na dinâmica econômica e social local.

[...] quase um mês sem trabalhar. Porque quem já chegou se instalou aí, antes de se instalar é uma maravilha. [...] depois que se instala o nativo é visto como um plano B. [...] Aqui quem está dominando são os turistas. [...] Aí, não pode falar alto se vai num caruruzinho, ou quando a gente vai trabalhar no loteamento; eles não procuram o encarregado do trabalho ou o trabalhador que está ali, pra resolver o problema entrando num acordo, para [...] resolver sem ter que parar o trabalho. Mas, não, o que está acontecendo é que eles dizem que se não parar vai chamar a polícia. É essa a maneira. Está certo? [...] vai chamar a polícia, a gente entende que como ele quer é guerra vai ter guerra. [...] diz que vai chamar a polícia a gente fica como se fosse bandido. E se acontecer de vir a polícia? [...] A maioria deles faz assim. [...] tem os crentes deles que de 12, 1 até 2 horas da manhã, mas da zoada deles ninguém fala nada. Quando a gente vai começar a trabalhar pra ganhar o pão aí está falando que não pode. [...] seis horas da manhã não pode. É que o transporte daqui é carroça. Seis horas da manhã tem que sair pra trabalhar porque tem que pegar carroça. [...] Começa na hora que eles querem e se estende até a hora que ele acha que deve trabalhar. [...] Aí na hora que a pousada tá pronta, entendeu, se eu precisar trabalhar aqui, quebrar uma parede minha [...] não pode. Ou seja, a gente vai acordar os clientes dele. Ele quem determina o horário. [...] O dele já está pronto. A coisa está braba aqui (OFICINA 1, 2010).

Essa longa narrativa evidencia que as tensões entre os moradores estabelecidos da ilha e os novos moradores, mesmo gerando postos de trabalho nos serviços ligados ao turismo, o que poderíamos considerar uma tensão entre atividades com desdobramentos positivos, tem produzido desdobramentos negativos, conflitos, tanto nas condições de sobrevivência quanto nas condições de organização na vida privada e na vida social coletiva. Práticas tradicionais em estigmatização; conteúdo de criminalização daquilo que é a rotina costumeira de muitas gerações frente à nova ordem; efetivamente, conflitos estruturais entre a reprodução da vida e a produção empresarial. O tempo do cotidiano da ilha, que é um tempo marcado pelo ritmo da natureza, passa a estar tensionado pelo ritmo das atividades do mercado turístico, que reproduz dinâmicas citadinas como a da vida noturna que, mesmo absorvida por moradores locais, não elimina o cotidiano de trabalho do dia seguinte, que se inicia com nascer do sol. Ademais, a pluriatividade de caráter multifuncional no uso dos equipamentos de trabalho também fica tensionada pelo padrão de serviço a ser oferecido no mercado turístico modernizado em superação ao mercado turístico customizado.

Nativo quase não tem. É um aqui outro ali. Pouquíssimos. [...] num barco meu lá embaixo que chegando perto do verão a gente pega pra fazer (transporte) [...] Ele não queria que esse barco, $[\ldots]$ não queria $[. .$.$] os transportes$ de viagem (OFICINA 1, 2010).

No depoimento mais emblemático das tensões decorrentes da atividade turística em Boipeba, nos dez a quinze anos de existência, revelam-se dimensões materiais no uso e apropriação da natureza e imateriais na correlação de forças sociais institucionalizadas em associações entre nativos, incluindo os estabelecidos de várias gerações, e os novos moradores:

[...] só tá piorando. Aqui tem um senhor que [...] pessoalmente eu não tenho nada contra ele... O dono da pousada fez assim, fez a pousada dele construindo com pedras tiradas da praia de Tassimirim. Quando terminou de fazer a bagaceira dele, ele fundou uma associação e onde se fez presidente sem direito de ninguém ser candidato pra concorrer com ele e ninguém mais pegou pedra ali (OFICINA 1, 2010).

É nesse processo de consolidação local da atividade turística moderna que na Associação de Moradores e Amigos de Boipeba a hegemonia passa a ser dos empresários do turismo, dando sentido ao sentimento de pescadores e marisqueiras, moradores "nativos", de que não estão representados em seus interesses e costumes. Retiraram-se. 


\section{O visível do gás na vida da Ilha}

A diversificação da matriz energética brasileira tem sido intensificada, tanto por motivos econômicos, dado o caráter não renovável do petróleo e seu anunciado esgotamento, quanto por motivos ambientais de conservação e de redução de poluentes. A produção de gás é caracterizada pela Lei 9.478/97, conhecida como Lei do Petróleo, que, em seu art. $6^{\circ}$, estabelece definições técnicas e traz no inciso II o conceito de gás natural ou gás como sendo todo hidrocarboneto que permaneça em estado gasoso nas condições atmosféricas normais, extraído diretamente a partir de reservatórios petrolíferos ou gaseíferos, incluindo gases úmidos, secos, residuais e gases raros (BRASIL, 1997).

Depois de tratado e processado, o gás natural tem diversas utilidades: na indústria como combustível para fornecimento de calor, geração de eletricidade e de força motriz, como matéria-prima nos setores químico, petroquímico e de fertilizantes, e como redutor siderúrgico na fabricação de aço; na área de transportes, é utilizado em ônibus e automóveis, substituindo o óleo diesel, a gasolina e o álcool; além disso, é ainda largamente utilizado em residências e no comércio (HENRIQUES JR., apud MOREIRA, 2005).

Como já mencionado no item sobre a pesca, a Petrobrás vem atendendo às condicionantes das diversas licenças relacionadas ao empreendimento na região; entretanto, um questionamento que encontramos na pesquisa de campo era a importância do destino dos recursos referentes à Compensação Ambiental e ao Projeto Compensatório. O projeto deveria promover compensações à atividade pesqueira sob diretriz de fomento a projetos locais voltados para o uso sustentável dos recursos pesqueiros, considerando as necessidades das comunidades pesqueiras, de modo que estivessem capacitadas a fazer a gestão dos recursos ambientais e pesqueiros da região, já que a perfuração para a exploração do gás ocorre em áreas rasas e sensíveis, onde a pesca artesanal é intensa. Contudo, segundo entrevista realizada em 2010, os recursos da compensação ambiental foram destinados à constituição, em sede alugada, de um Centro Cultural, com finalidade de Educação Ambiental e criação de usina de reciclagem, sob a responsabilidade da AMABO. Os recursos do Projeto Compensatório estão sendo destinados para a construção de um Centro Comunitário, sob responsabilidade da Associação de Pescadores, já que a comunidade não aceitou mais a mediação da AMABO, que consiste num "local para a comunidade se reunir, fazer exposição, ter um centro cultural" (Sr. Tião, presidente da Associação dos Pescadores).
O reconhecimento da existência de atividade pesqueira artesanal intensa e o cumprimento das exigências legais sugerem uma relação sem fortes conflitos com a população de pescadores e marisqueiras. Contudo, na fase exploratória da pesquisa (2009), foi possível apreender que a forma de inserção das empresas do consórcio Manati, na comunidade local, através da entrega dos documentos de EIA e RIMA e do Projeto de Compensação, não está plenamente absorvida em termos positivos.

\begin{abstract}
Quando veio foi o pessoal da El Paso que veio e deu esse negócio aí. Deu uma cópia pra todo mundo. A El Paso, ela não sai daqui... O Projeto [...] Foram lá, discutiram lá e não resolveram nada. Iam fazer uma fábrica de gelo. [...] A verba saiu. [...] Os vereadores mesmo falaram, na reunião. O dinheiro saiu, com certeza. [...] o dinheiro que chega pra o pescador não chega pra mão do pescador... pra resolver esse negócio aí [Centro Cultural], juntou Colônia, Associação dos Pescadores e eles [AMABO] só que a Colônia, eles tiraram de fora e ficaram só com a máfia deles lá... E até hoje a gente não sabe o resultado, porque [o presidente da Colônia] ele gosta de lutar pelos pescadores. [...] mas o pior é que os próprios moradores daqui têm medo de enfrentar o grandão [...] aqui, faz uma reunião, todo mundo mete a boca, mas na hora de cara a cara lá com o homem, ninguém fala nada. [...] [O presidente da Colônia] concorreu pra ser vereador, fizeram tanta coisa pro pessoal não votar nele, pra impedir, que o homem não se elegeu (GF, 2009).
\end{abstract}

Essa síntese de depoimentos evidencia relações de poder local que se fortalecem e que se enfraquecem a partir das injunções legais e de gestão institucional, decorrentes da atividade de exploração de gás, por ser motivadora de movimentação financeira até então não experimentada em escala local, ficando secundarizado o foco da compensação ambiental. No processo de elaboração do Projeto Participativo Compensatório da Velha Boipeba, diante da cogitação de se construir uma quadra esportiva, teria sido questionado:

venha cá, a população vai ficar jogando bola? Não vai. Os pescadores precisam de um negócio de gelo [...] Igor até disse até que doava o terreno [...] é um vereador que ganhou agora e que doava o terreno; tem um bocado de terreno aqui. Não quiseram, não!! Não aceitaram (GF, 2009). 
As tensões estabelecidas entre a atividade de exploração de gás e a tradicional atividade pesqueira na ilha de Boipeba não se constituem por processos de contaminação do ambiente físico decorrente da exploração de gás, até porque não se tem registro de aferição dessa contaminação, embora haja registro de animais mortos no mar e nas praias da ilha sem que se expliquem as causas. As tensões estão no âmbito das relações sociais, econômicas e políticas; disputas na apropriação da natureza, dos recursos financeiros e das estruturas de poder.

Ademais, o perfil da atividade anuncia novos problemas tendo em vista seu tempo curto de vitalidade com intenso investimento. Conforme dados da Agência Nacional do Petróleo, Gás Natural e Biocombustíveis - ANP -, o Brasil tem uma produção crescente de gás natural - terra e mar -, tendo chegado em 2000 ao volume de 13.282.381 milhões de $\mathrm{m}^{3}$. Em 2008, temos o registro da maior produção: 21.592.652 milhões de $\mathrm{m}^{3}$, cujo declínio atinge 10.286.381 milhões $\mathrm{m}^{3}$ apenas no primeiro semestre de 2009 (jan.-jun./2009). Já nos dados para o Estado da Bahia, a produção de gás natural no mar teve um crescimento bastante significativo em 2007, época em que teve início a produção em Manati; entretanto, comparando-se 2009 com o mesmo período de 2008, registra-se uma queda na produção em 176.224 milhões de $\mathrm{m}^{3}$, o que causa preocupação, pois sabendo que este é um recurso natural não renovável e finito, o fim da produção trará em consequência o não pagamento de royalties e demais tributos vinculados ao processo produtivo e produto comercializado.

As tensões explicitam a apropriação desigual dos benefícios dessa atividade, como ilustra o depoimento a seguir obtido em entrevista coletiva (2010):

Melhorou pro pessoal que tem barco. Benefícios que eles trouxeram aqui foi esse negócio pra quem tem barcos, [...] É, eu não tive beneficio nenhum, que não tenho barco, essas coisas. [...] A única melhoria que eles fizeram foi para quem tem embarcação. [...] E praticamente não é nem meu porque se eu vender para outra pessoa o equipamento volta pra eles (EC 1, 2010).

Outra compreensão registrada é de que

O Manati até agora beneficiou 300 moradores, o pescador não pode dizer que não tem beneficio, sim, porque é uma das coisas que ajudou muito e ainda vai ajudar, porque vem um rádio que não tinha nada, e um [...] de gelo, antes tinha que levar isopor. E quando quebrava ficava a ver navio, não tinha rádio nem nada (EI 1, 2010).

Evidencia-se mais uma vez que a reprodução de assimetrias sociais na diversidade de correlações de forças entre níveis econômicos da população é uma dimensão visível da presença da exploração de gás, geradora de risco ambiental e por isso regulada pelo poder público, onde o cumprimento da regulação se desdobra em eventos socioambientais de largo espectro por tensionar modo de vida, condições de produção material na economia tradicional local e relações sociais da vida coletiva.

\section{Finalizando}

A gestão ambiental e o desenvolvimento turístico sustentável da costa do dendê, temas articuladores desta pesquisa, ficam reafirmados como problemática relevante e a ser implementada na Velha Boipeba, onde a compreensão da dinâmica da vida na ilha a partir das atividades turísticas e de exploração de gás sugere tratar-se de um fenômeno (des)organizativo que parece ter sido acirrado com a ingerência dos agentes ambientais desde os estudos de impacto ambiental, passando pelo relatório de impacto ambiental e chegando com reforço de assimetrias à intervenção para compensação ambiental. Uma das evidências do reforço às assimetrias está na reiterada afirmação de que os benefícios compensatórios que chegaram às mãos dos pescadores ficaram restritos àqueles que têm barco, em torno de $20 \%$.

Também se evidenciam tensões entre as atividades de pesca artesanal e turismo, mediadas pela extração de gás, pondo em disputa a produção material e a produção social da vida ao mercantilizar manifestações culturais próprias do cotidiano da população da ilha; simultaneamente, reduz nesse mesmo cotidiano a produção material, que garante a reprodução social dos pescadores, e espetaculariza manifestações da tradição cultural como elemento identitário. O turismo passa a sobredeterminar a produção material e a subsumir a produção social pela mercantilização da cultura. Assim, a dinâmica do mercado local, sob diretriz e financiamento de políticas de desenvolvimento econômico e de regulação ambiental, reproduz a ordem de mercado capitalista sob constrangimentos ambientais e sem sustentabilidade socioambiental efetiva no desenvolvimento induzido. 
A ruralidade, originalmente insular dos moradores da ilha de Boipeba, se reconfigura, então, como uma ruralidade em estreita inter-relação subalterna com o desenvolvimento urbano/industrial/metropolitano; reconfigura-se como

\section{Referências}

ALENCAR, Cristina Maria Macêdo de. Ruralidade: ponto em comum para reexaminar o ordenamento metropolitano de Salvador. Revista Veritati, UCSAL, BA, p. 10-42, 2003.

. Na ruralidade metropolitana o encontro da ruralidade com a expansão da metrópole. In: SEMINÁRIO INTERNACIONAL “A EXPANSÃO DA METRÓPOLE PARA ALÉM DAS FRONTEIRAS DA SUA REGIÃO - CONTINUIDADE OU RUPTURA?". Anais... RJ, IPPUR, 2009.

AUGÉ, Marc. Não-lugares: Introdução a uma antropologia da supermodernidade. Tradução de Maria Lúcia Pereira. São Paulo: Papirus, 1994. Coleção Travessia do Século.

BAHIA. Plano de Desenvolvimento Integrado do Turismo Sustentável, PRODETUR-PDITS. 2004.

BENSAÏD, D. Marx: o intempestivo. Rio de Janeiro: Civilização Brasileira, 1999.

BRANDÃO, Carlos. Território e desenvolvimento: as múltiplas escalas entre o local e o global. Campinas: Editora UNICAMP, 2007.

BRASIL. Presidência da República. Lei $n^{\circ}$ 9.478, de 06 de agosto de 1997. Dispõe sobre a política energética nacional, as atividades relativas ao monopólio do petróleo, institui o Conselho Nacional de Política Energética e a Agência Nacional do Petróleo e dá outras providências. Disponível em: <http:// www.planalto.gov.br/ccivil_03/Leis/L9478.htm>. Acesso em: 01 jul. 2009.

CARNEIRO, M J. Ruralidade: novas identidades em construção. Estudos Sociedade e Agricultura, Rio de Janeiro: CPDA/ UFRRJ, n. 11, out. 1998.

CASTRO-GÓMEZ, Santiago. Ciencias sociales, violencia epistémica y el problema de la "invención del, otro". In: LANDER, Edgardo (Comp.). La colonialidad del saber: eurocentrismo y ciencias sociales. Perspectivas Latinoamericanas. Secretaria Ejecutiva CLACSO, 2001.

CONCHEIRO, Luciano. Los Azarosos Caminos. In: GONZÁLEZ, Mario; HUACUJA, Ivonne (Coord.). Estudios e ruralidade metropolitana, expressando desenvolvimento enquanto processo histórico, desigual e combinado, ambientalmente constrangido na crise da razão instrumental capitalista.

investigaciones: nueva ruralidad. Enfoques y propuestas para América Latina. México: CEDRSSA, 2006.

D’AMBRÓSIO, U. Educação para uma sociedade em transição. São Paulo: Papirus, 1999.

DIEGUES, A. C. Ilhas e mares: simbolismo e imaginário. São Paulo: Hucitec, 1998.

DURÁN, F. E. Velhas e novas imagens sociais de ruralidade. Revista Sociedade e Agricultura, Rio de Janeiro, CPDA/ UFRRJ, n. 11, 1999.

El PASO \& SOMA. Projeto de compensação da atividade pesqueira: relatório descritivo fase II - DRP (revisão 01). 2007.

FISCHER, A. Tempo e ordenamento do território: algumas reflexões. In: FIRKOWSKI, OLC.; SPOSITO E. Indústria, ordenamento do território e transportes. A contribuição de André Fischer. São Paulo: Expressão Popular, 2008.

FLEXOR, M. H. O. Evolução histórica do Baixo Sul na formação da economia do Recôncavo Sul da Bahia. In: FUNDAÇÃO ODEBRECHT. Desenvolvimento sustentável, a visão e a ação de um empresário. O caso do Baixo Sul da Bahia. Salvador: Neama - CRA - Fundação Odebrecht, 2004.

FREIRE, P. A pedagogia da autonomia: saberes necessários à prática educativa. São Paulo: Paz e Terra, 1996.

GOMES, M. A. O.; SOUZA, A. V. A.; CARVALHO, R. S. Diagnóstico Rápido Participativo (DRP) como mitigador de impactos socioeconômicos negativos em empreendimentos agropecuários. In: BROSE, Markus (Org.). Metodologia participativa: uma introdução a 29 instrumentos. Porto Alegre: Tomo Editorial, 2001.

HAESBAERT, R.; PORTO-GONÇALVES, C. W. A nova des-ordem mundial. São Paulo: UNESP, 2005.

HERÉDIA, Beatriz Maria Alásia de. A morada da vida. Rio de Janeiro: Paz e Terra, 1979.

LEFF, Enrique. Ecologia, capital e cultura. Petrópolis: Vozes, 2009. 
LENOBLE, R. História da ideia de natureza. Rio de Janeiro: Edições 70, 1969.

MOREIRA, L. B. C. Avaliação dos aspectos ambientais da geração de energia através de termoelétricas a gás natural. Dissertação (MS Profissional em Gerenciamento e Tecnologias Ambientais no Processo Produtivo) - Politécnica UFBA. Salvador, 2005.

MOREIRA, Roberto José. Economia política da sustentabilidade: uma perspectiva neomarxista. In: COSTA, L. F. C.; MOREIRA, R. J.; BRUNO, R. (Org.). Mundo rural e tempo presente. Rio de Janeiro: Mauad, 1999.

Ruralidades e globalização: ensaiando uma interpretação. Rio de Janeiro: CPDA/UFRRJ, 2002. Caderno Ruralidades.

; GAVIRIA, M. R. Territorialidades, ruralidades e assimetrias de poder na comunidade de Taquari. Estudos Sociedade e Agricultura, n. 18, p. 47-72, abr. 2002.

MORIN, Edgar. Ciência com consciência. Rio de Janeiro: Bertrand Brasil, 1996.

MURICY, Ivana Tavares. Potencialidades e limites do turismo para o desenvolvimento das sociedades. Série Estudos e Pesquisas, Salvador: SEI, n. 82, p. 29-56, 2009.

OLIVA, A. Ciência e sociedade do consenso à revolução. Campinas: UNICAMP, 1998.

PEDRÃO, Fernando. Economia, política e poder na periferia globalizada. Salvador: JusPodium, 2009.

SANTOS, Boaventura de Sousa. Pela mão de Alice. O social e o político na pós-modernidade. São Paulo: Cortez, 1995.

SANTOS, M. A natureza do espaço. São Paulo: EDUSP, 2004.
SEMA. Disponível em: <http://www.semarh.ba.gov.br/ conteudo.aspx? $\mathrm{s}=$ APATINHA $\& p=$ APAAPA $>$. Acesso em: março de 2009.

SILVA, Iracema Reimão. Avaliação da sensibilidade socioeconomica e ambiental para derrames de óleo da Costa do Dendê, sul do Estado da Bahia. Relatório de Pesquisa CNPq. Salvador: UCSAL, 2007.

TOURAINE, Alain. Os novos conflitos sociais: para evitar mal-entendidos. Rev. Lua Nova, São Paulo, n. 17, p. 5-18, jun. 1989.

VEIGA, José Eli da. Nascimento de outra ruralidade. Estudos Avançados, São Paulo: USP, v. 20, n. 57, p. 333-353, 2006.

WANDERLEY, M. N. A emergência de uma nova ruralidade nas sociedades avançadas - o rural como espaço singular e ator coletivo. Est. Soc. e Agric., n. 15, p. 87-146; out. 2000.

\section{Fontes Orais}

EI 1. Entrevista Individual Anônimo 1, Boipeba, março de 2009.

GF 2009. Grupo focal com pescadores, Boipeba, março de 2009.

OFICINA 1 2010. Oficina em grupo focal com pescadores, Boipeba, janeiro de 2010.

GF 1 2010. Grupo focal com pescadores, Boipeba, janeiro de 2010 .

EC 1 2010. Entrevista coletiva com pescadores, Boipeba, janeiro de 2010.

EI 1 2010. Entrevista Individual Gestor Público Anônimo, Boipeba, janeiro de 2010.

Recebido em outubro de 2010.

Aceito em dezembro de 2010

Publicado em junho de 2011. 